\title{
VITAMIN D FROM FOOD AND SUPPLEMENT INTAKE IN PREGNANCY. A PILOT STUDY
}

\author{
CORINA ZUGRAVU ${ }^{1,2 \#}$, AGRIPINA RAȘCU ${ }^{1 \#}$, MARINA RUXANDRA OȚELEA ${ }^{1 *}$, ADRIANA \\ MACRI $^{3}$
}

1 "Carol Davila" University of Medicine and Pharmacy, Bucharest, Romania

${ }^{2}$ National Institute of Public Health, Bucharest, Romania

${ }^{3}$ National Institute of Research and Development for Food Bioresources, Bucharest, Romania

*corresponding author: marina.otelea@umfcd.ro

${ }^{\#}$ Authors with equal contribution.

\begin{abstract}
Pregnancy is a challenging period for the women in terms of metabolic needs, the intake of nutrients having to cover mother and foetus necessities. Studies have shown that vitamin D is frequently deficient in our geographical area, with dire consequences in pregnancy. In the present pilot study, a sample of Romanian pregnant women $(n=372)$ was investigated for the vitamin D intake from foods and supplements. Results confirmed the insufficiency of the intake, which was far below the recommended level (median: 63.91 IU per day). Supplements were consumed only by 71 women and their contribution to the total intake was minimal. Special attention has to target vitamin D assessment during pregnancy; its consumption should be monitored and, if needed, adequate supplementation and diet modifications should be provided.
\end{abstract}

\section{Rezumat}

Perioada de graviditate este o perioadă dificilă pentru femeie, din punct de vedere metabolic, trebuind acoperite atât nevoile gravidei, cât și ale fetusului. Studiile au arătat că vitamina D este frecvent deficitară în arealul nostru geografic, ceea ce poate avea urmări importante în graviditate. În studiul de față, un lot de 372 de gravide a fost investigat din punct de vedere al aportului de vitamina D din alimente și suplimente. Rezultatele au confirmat aportul necorespunzator, mult sub nivelul recomandat (mediana: 63,9 UI pe zi). Doar 71 de femei au consumat suplimente vitaminice, a căror contribuţie la aportul de vitamina D a fost minimă. În consecință, trebuie acordată o atentie aparte asigurării necesarului de vitamina D în timpul sarcinii, aportul trebuie monitorizat și, acolo unde se constată un deficit, trebuie recomandate suplimente și alimente bogate în această vitamina.

Keywords: habitual food intake, pregnancy, vitamin D supplementation, vitamin D deficiency

\section{Introduction}

Pregnancy is a challenging period in terms of metabolic needs; nutrition or substitution should cover not only the foetuses' needs, but also the enhanced requirements of the women's metabolism to assure a smooth evolution of the pregnancy. The nutrient intake during pregnancy influences also the postnatal health, e.g the post-partum recovery and breastfeeding. Studies have shown that one of the most frequent deficiency in our geographical area is vitamin D deficiency $[1,2]$. In a large study that covered almost 56,000 persons, it has been internationally shown by means of a standardized dataset that $13 \%$ of EU residents living at latitude gradient of $35^{\circ} \mathrm{N}$ to $69^{\circ} \mathrm{N}$, had serum levels of $25(\mathrm{OH}) \mathrm{D}<30 \mathrm{nmol} / \mathrm{L}$ and $40 \%$ had $<50 \mathrm{nmol} / \mathrm{L}$ [3]. It was stated that vitamin $\mathrm{D}$ deficiency has been recognized as a pandemic with a myriad of health consequences [4]. Consequences during pregnancy are significant and avoiding them should be a priority. Vitamin D deficit increases the risk of preeclampsia, and is associated with low birth weight, neonatal hypocalcaemia, weak postnatal growth, bone fragility, and increased incidence of autoimmune diseases [5, 6]. Also a low prenatal and neonatal vitamin D may increase the susceptibility for schizophrenia, type 1 diabetes, and multiple sclerosis (MS) in adult life, by specific target organ effects, like through the immune system, or through epigenetic modulation [7]. Studies carried out in Romania during the last decade confirm that vitamin D intake is not sufficient and young women are one of the most prevalent risk groups [1]. It was also reported that supplementation with usual doses during pregnancy does not always succeeded in normalizing the circulating level of $25 \mathrm{OH}$ cholecalciferol [5]. The primary source of vitamin $\mathrm{D}$ is, in theory, the skin, that synthetizes vitamin D under the action of sunlight. The endogenous synthesis covers almost $90 \%$ of the needs of 
vitamin D. All recent studies, however, confirm that for modern, indoor working and living people, sun exposure has a minimal contribution and that the vitamin must be provided using food sources and supplements [1]. Studies carried out on pregnant women showed that season (sun exposure) and supplements could hardly correct pre-existing deficiencies [8]. Food sources of cholecalciferol are rather scarce, and their consumption might be too low to cover the need for the vitamin since most of them are highly caloric and sometimes avoided mainly by young fertile women who frequently follow slimming diets. Fat fish, fat meat, liver, meat products are not staples of a healthy diet. Fish, one of the primary sources, is advised to be consumed moderately, due to its content of different pollutants [9]. Modern nutrition does not recommend a frequent consumption of meat products since their effects on health seem harmful [10]. Dietary products are not vitamin D usually fortified in Romania, and most of them lose the natural content of vitamin D during skimming. Supplements might be the solution. Still, they are not given routinely to young women nor have an insufficient level of vitamin D. Taking into consideration this framework, we evaluated the intake of vitamin D from current food sources and usual pregnancy supplements in a sample of pregnant women and have assessed the need of action and the solutions to correct the possible insufficient intake.

\section{Materials and Methods}

We carried out a transversal semi-quantitative pilot survey on 372 pregnant women from different regions of Romania. To get a working sample, midwife students from the "Carol Davila" University of Medicine and Pharmacy from Bucharest, Romania were asked to recruit pregnant women during their summer practice (2018). All the positive responders signed an informed consent and completed a questionnaire applied by the students during a planned meeting in the spring of 2019. The initial number of participants was 489 ; however, due to the length of the questionnaire, 24\% dropped out, the final number of the sample is 372 . The survey used a food frequency questionnaire based on a validated adjusted form of the original EPICNorfolk survey. It had several sections, designed to gather demographic, socio-economic and dietary data. The original EPIC-Norfolk was first developed in the year 1988 and consisted of food lists and portion sizes likely to be consumed by adults [11]. Due to the scarcity of food sources of vitamin $D$, in the present study we considered the following food groups, recognized in literature as having a specific content of vitamin: meat and meat products, fish and seafood, eggs, milk products (including milk-based deserts), other industrial fats of animal origin, (including supplemented fats, such as margarines). In Romania food is seldom fortified with vitamin $\mathrm{D}$, with margarines as an exception. Therefore, we did not consider other presumed sources (morning cereal for adults, orange juice), as well as UV exposed mushrooms, which are not present on the Romanian market. Levels of vitamin $\mathrm{D}$ in each food group were defined using the program "Chronometer" (chronometer.com). This program compiles food composition data from the NCCDB (Nutrition Coordinating Centre Food \& Nutrient Database of the University of Minnesota), USDA SR28 (United States Department of Agriculture National Nutrient Database for Standard Reference), the CNF (Canadian Nutrient File) and IFCDB (Irish Food Composition Database). A special section of the questionnaire covered supplement consumption. This section includes questions about the intake, the dose and the brand.

Statistical analysis

Statistical analysis and plotting were performed using SPSS 12.0. Descriptive, correlation, non-parametric and classification tests were applied and63 $\mathrm{p}$ values $\leq 0.05$ were considered statistically significant. The Ethics Committee of the National Institute of Research and Development for Food Bioresearches, Bucharest, Romania assessed and approved the study.

\section{Results and Discussion}

Most of the women $(67.5 \%)$ participating in the study were included in the 25 - 34.9 years of age interval and lived in urban areas. Only one respondent came from a rural area. All women had indoor professional activities, as clerks, teachers, assistants, accountants etc. thus excluding the critical contribution of sun exposure to vitamin D synthesis. Distribution by month of pregnancy varied, from one month, to 9 months, with a median value of 4 months. Most women had a high educational level which is generally an indicator of proper nutrition and health knowledge. The mean quantity of vitamin D intake from food was $69.84 \mathrm{IU} /$ day $(\mathrm{SD}=35.2)$, with a median of 63.91 IU, a minimum of 5.65 IU and a maximum, of 240.67 IU (Figure 1). These values are congruent with those found in a previous Romanian study [1], where the median intake for women of all ages was $63.4 \mathrm{IU} /$ day but are unexpected because pregnant women tend to follow more closely healthy nutrition recommendations for fear of harming the baby [12]. The age did not correlate significantly with the intake of vitamin D. However, higher consumption was observed for the 18 - 24.5 years group (group 2) and the over 35 years group (group 4) (Figure 2). The intake in the 25 - 34.9 years group (group 3) has more significant dispersion, with cases reaching the highest intake from the entire sample but also with others within the lowest intake range. 


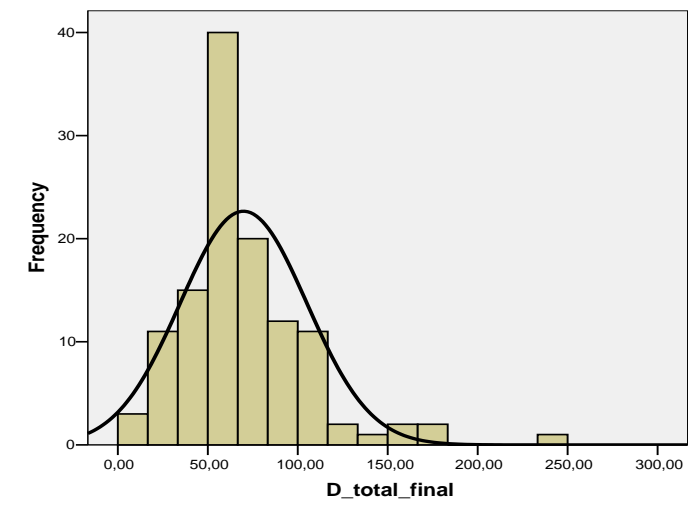

Figure 1.

Distribution of vitamin D intake values (IU/day)

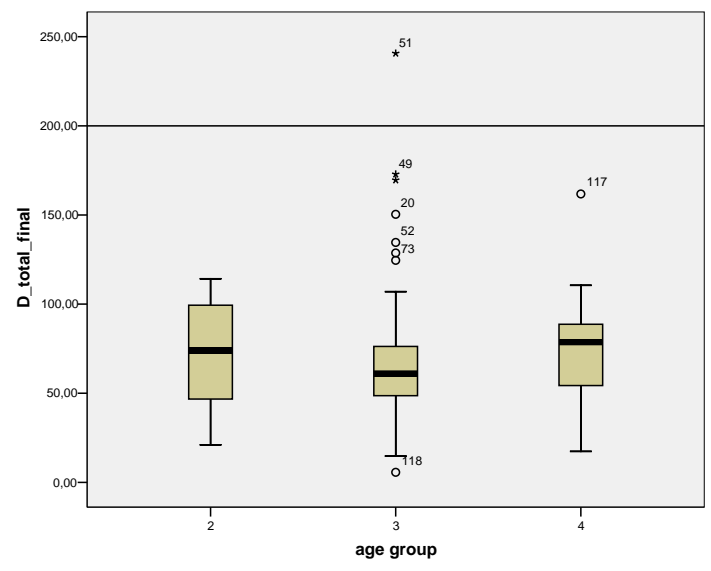

Figure 2.

Vitamin D intake (IU/day) from all sources, on age group (group $2=18-24.9$ years; group $3=25-34.9$ years; group $4=35-45$ years)

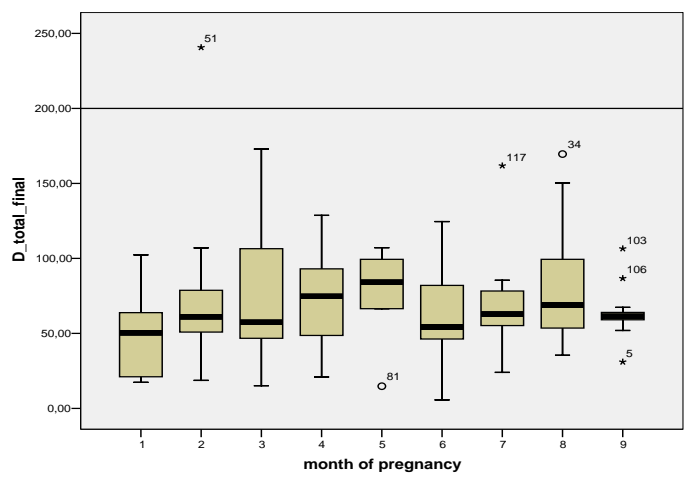

Figure 3.

Vitamin D intake (IU/day) from all sources on correlated with the month of pregnancy

From the study participants sample, only one respondent had an intake of more than 200 IU/day, the daily intake recommended in Romania (13). All the respondents had an intake far below the recommended level by European Food Safety Authority (EFSA) (15 $\mu \mathrm{g}$ - 600 IU/day) [14]. The intake did not correlate with the month of pregnancy. Postulated lower intakes in the first three months due to pregnancy-related nausea were not confirmed by our evaluation (Figure 3).

From different groups of foods, the following have a consumption correlating significantly with the intake of vitamin $\mathrm{D}$, due of their high content and intake in this sample: fish and fish preserves $(\mathrm{p}=$ $0.00)$, roes $(p=0.00)$, sausages $(p=0.02)$, meat preserves $(p=0.032)$, liver and pate $(p=0.00)$, milk $(p=0.001)$, cheese $(p=0.001)$ and full fat sour cream $(p=0.002)$. However, in our study, the most proeminent influence is shown by fish and fish preserves and roes, which can boost the levels of intake (from the lowest quartile of consumption, to the highest) even if consumed only once per week. Supplement consumption was reported only by $19.08 \%(n=71)$ of the women. From them, 52 were taking Femibion ${ }^{\circledR} 1$ or 2 , which lacks vitamin D and 19, Elevit Pronatal ${ }^{\circledR}$, with a content of $500 \mathrm{IU}$ vitamin D3 per tablet. The intake of supplements did not correlate with the stage of pregnancy $(\mathrm{p}=0.67)$ or with the food intake $(\mathrm{p}=0.82)$, but did correlate statistically significant with education $(\mathrm{p}=0.00)$ and income $(\mathrm{p}=0.00)$.

Indeed, there is an enhancement of vitamin $\mathrm{D}$ metabolism in pregnancy and lactation. The placenta is formed at four weeks of gestation. From its formation to term, $25(\mathrm{OH}) \mathrm{D}$ crosses the placenta. Thus, the foetal cord blood concentration of $25(\mathrm{OH}) \mathrm{D}$ reflects the mother's serum levels [15]. But the active metabolite of vitamin $\mathrm{D}, 1,25(\mathrm{OH}) 2 \mathrm{D}$, does not cross the placenta. There are the kidneys of the foetus and the placenta itself that provide the foetal circulation with $1,25(\mathrm{OH}) 2 \mathrm{D}$, through the expression of CYP27B1 [16]. Vitamin D has, per se, a role in the placental development [17]. A recent Cochrane systematic review states that "Supplementing pregnant women with vitamin D alone probably reduces the risk of pre-eclampsia, gestational diabetes, low birth weight and may reduce the risk of severe postpartum haemorrhage" [18]. Prenatal to postpartum supplementation can be an efficient intervention in increasing the mother's vitamin D status and in assuring an adequate vitamin D status in new-borns and breastfed infants [19], and is frequently required to achieve a sufficient vitamin D status in pregnant women [20]. The United Kingdom, for example, the Department of Health recommends that pregnant women take 400 IU vitamin D daily, to prevention of neonatal hypocalcaemia [21]. Recent studies demonstrated that vitamin $\mathrm{D}$ deficiency during pregnancy could have short and long term effects on mother (impairement of the bone density) and child foetal skeletal formation, and chronic disease susceptibility) [22]. Comparing to other micronutrients such as iodine [23] and iron [24] an appropriate vitamin D assessment and supplement recommendation in deficient or insufficient pregnant women is not enough highlighted in practice. In this respect, clear guidelines to identify the risk for 
insufficiency in pregnant women are recommended for both the mother and child [25]. Vitamin D has various roles in the human body, acting as an immunomodulatory component in children [26] and adult asthma [27] and other respiratory disorders [28]. Evidence from a systematic review of randomized control trials (the PROSPERO study) shows that even if supplements did not correlate with a lower rate of pre-term birth, the sufficient prenatal vitamin $\mathrm{D}$ reduced the risk of offspring wheeze by the age of three years old. However, the evidence to date is still not sufficient in order to be a fundament for further or policy recommendations [30]. The same conclusions can be found in different systematic reviews, where the primary outcomes of interest were preterm delivery, pre-eclampsia, maternal and childhood infections and small for gestational age [31]. Updated guidelines have underlined that supplementation during pregnancy is needed to protect against adverse pregnancy outcomes [18]. However, studies showed that maternal vitamin D supplementation during pregnancy and lactation does modify methylation of DNA both in mothers, and breastfed infants. In consequence, more research is needed to bring light on the short- and long-term biologic effects of supplementation in different doses [32]. Timing, and dosage of the supplements are still under research and hopefully, the near future will bring new updates in this domain. Apart from supplements, food fortification might also be a component of great importance from the public health standpoint [29, 33]. The ODIN study underlined that strategies of fortification could heighten the intake of vitamin D and avoids deficiencies [34], which could hold important implications for establishing clinical recommendations for prenatal and offspring health promotion.

\section{Conclusions}

Implementation of a standard protocol to assess vitamin D during pregnancy is needed. Besides proper nutritional counselling, a supplement should be prescribed in cases of deficit or insufficiency. Practical communication tools might contribute to the increase of the medical community and the public awareness of the importance of vitamin D during the perinatal period.

\section{Acknowledgement}

This study was achieved through Core Program, with the support of the Ministry of Research and Innovation (MCI), contract 22N/2019, project PN 19020102 .

\section{Conflict of interest}

The authors declare no conflict of interest.

\section{References}

1. Zugravu C, Tarcea M, Soptica F, Cucu A, Pertinence of vitamin D supplementation in the adult Romanian population. Farmacia, 2016; 64(3): 467-472.

2. Niculescu DA, Capatina CAM, Dusceac R, Caragheorgheopol A, Ghemigian A, Poiana C. Seasonal variation of serum vitamin D levels in Romania. Arch Osteoporos., 2017; 11; 12(1): 1-7.

3. Kiely M, Cashman KD, Summary outcomes of the ODIN project on food fortification for vitamin D deficiency prevention. Int J Environ Res Public Health, 2018; 15(11): 1-14.

4. Hossein-nezhad A, Holick MF, Vitamin D for health: a global perspective. Mayo Clin Proc., 2013; 88(7): 720-755.

5. Bohiltea RE, Zugravu C, Neacsu A, Navolan D, Berceanu C, Nemescu D, Bodean O, Turcan N, Baros A, Cirstoiu MM, The prevalence of vitamin D defficiency and its obstetrical effects, a prospective study on Romanian patients. Rev Chim (Bucharest), 2019; 70(4): 1228-1233.

6. Mulligan ML, Felton SK, Riek AE, BernalMizrachi C, Implications of vitamin D deficiency in pregnancy and lactation. Am J Obstet Gynecol., 2010; 202(5): 1-17.

7. Lucas RM, Ponsonby AL, Pasco JA, Morley R, Future health implications of prenatal and early-life vitamin D status. Nutr Rev., 2008; 66(12): 710-720.

8. Kramer CK, Ye C, Swaminathan B, Hanley AJ, Connelly PW, Sermer M, Zinman B, Retnakaran R, The persistence of maternal vitamin $\mathrm{D}$ deficiency and insufficiency during pregnancy and lactation irrespective of season and supplementation. Clin Endocrinol., 2016; 84(5): 680-686.

9. Kimáková T, Kuzmová L, Nevolná Z, Bencko V, Fish and fish products as risk factors of mercury exposure. Ann Agric Environ Med., 2018; 25(3): 488-493.

10. Bradbury K, Murphy N, Key T, Diet and colorectal cancer in UK Biobank: A prospective study. Int $J$ Epidemiol., 2019; 0(0): 1-13.

11. The EPIC-Norfolk Food Frequency Questionnaire and FETA Software

12. Forbes LE, Graham JE, Berglund C, Bell RC, Dietary change during pregnancy and women's reasons for change. Nutrients, 2018; 10(8): 1-10.

13. Graur M, Guide to healthy eating, tips for the population. Second edition, revised and completed. Grigore T. Popa Publishing House, Iasi, Romania, 2014 (available in Romanian).

14. EFSA Panel on Dietetic Products, Nutrition and Allergies (NDA), Dietary reference values for vitamin D. EFSA Journal, 2016; 14(10); 1-145.

15. Shin JS, Choi MY, Longtine MS, Nelson DM, Vitamin D effects on pregnancy and the placenta. Placenta, 2010; 31(12): 1027-1034.

16. Adams JS, Hewison M, Extrarenal expression of the 25-hydroxyvitamin D-1-hydroxylase. Arch Biochem Biophys., 2012; 523(1): 95-102.

17. Evans KN, Bulmer JN, Kilby MD, Hewison M, Vitamin D and placental-decidual function. J Soc Gynecol Investig., 2004; 11(5): 263-271. 
18. Palacios C, Kostiuk LK, Peña-Rosas JP, Vitamin D supplementation for women during pregnancy. Cochrane Database Syst Rev., 2019; 26; 7: 1-151.

19. Thiele DK, Ralph J, El-Masri M, Anderson CM, Vitamin D3 supplementation during pregnancy and lactation improves vitamin D status of the motherinfant dyad. J Obstet Gynecol Neonatal Nurs., 2017; 46(1): 135-147.

20. Pilz S, Zittermann A, Obeid R, Hahn A, Pludowski $\mathrm{P}$, Trummer C, Lerchbaum E, Pérez-López FR, Karras SN, März W, The role of vitamin D in fertility and during pregnancy and lactation: a review of clinical data. Int J Environ Res Public Health, 2018; 15(10): 1-19.

21. Curtis EM, Moon RJ, Harvey NC, Cooper C, Maternal vitamin D supplementation during pregnancy. Br Med Bull., 2018; 126(1): 57-77

22. Lapillonne A, Vitamin D deficiency during pregnancy may impair maternal and fetal outcomes. Med Hypotheses., 2010; 74(1): 71-75.

23. Ursu HI, Toader OD, Podia-Igna C, Delia CE, Firta AR, Tupea CC, Tudor LM, Gheorghiu ML, Suciu $\mathrm{N}$, Iodine status in pregnant women after a decade of universal salt iodization in Romania. Acta Endocrinol (Bucharest), 2016; 12(2): 161-167.

24. Stativa E, Rus AV, Stanescu A, Pennings JS, Parris SR, Wenyika R, Prevalence and predictors of anaemia in Romanian infants 6 - 23 months old. $J$ Public Health, 2016; 38(3): 272-281.

25. Fanos M, Vierucci F, Saggese G, Vitamin D in the perinatal period: An update. J Pediatr Neonat Individual Med., 2013; 2(2): 1-9.

26. Litonjua A, Vitamin D and childhood asthma. Curr Opin Allergy Clin Immunol., 2019; 19(2): 126-131.

27. Otelea MR, Rascu A, Vitamin D Intake and obesity in occupational asthma patients and the need for supplementation. Endocr Metab Immune Disord Drug Targets, 2018; 18(6): 565-572

28. Martineau Adrian R, Jolliffe David A, Hooper Richard L, Greenberg Lauren, Aloia John F, Bergman P, Vitamin D supplementation to prevent acute respiratory tract infections: Systematic review and meta-analysis of individual participant data. BMJ, 2017; 356: i6583.

29. Nan R, Grigorie D, Cursaru A, Șucaliuc A, Drăguț R, Rusu E, Muşat M, Radulian G, Bisphosphonates a good choice for women with type 2 diabetes and postmenopausal osteoporosis?. Farmacia, 2016; 64(2): 257-261.

30. Roth DE, Leung M, Mesfin E, Qamar H, Watterworth J, Papp E, Vitamin D supplementation during pregnancy: state of the evidence from a systematic review of randomised trials. BMJ, 2017; 359: j5237.

31. Thorne-Lyman A, Fawzi WW, Vitamin D during pregnancy and maternal, neonatal and infant health outcomes: a systematic review and meta-analysis. Paediatr Perinat Epidemiol., 2012; 26(Suppl 1): 75-90.

32. Anderson CM, Gillespie SL, Thiele DK, Ralph JL, Ohm JE, Effects of maternal vitamin D supplementation on the maternal and infant epigenome. Breastfeed Med., 2018; 13(5): 371-380.

33. Stancu E, Tăerel AE, Soroceanu V, Rais C, Ghica $\mathrm{M}$, Ethical aspects of food supplements in EU and Romania. Farmacia, 2019; 67(4): 736-742.

34. Kiely M, Cashman KD, Summary outcomes of the ODIN project on food fortification for vitamin D deficiency prevention. Int $J$ Environ Res Public Health, 2018; 15(11): 1-14. 